\title{
HOW TO HELP YOUR STUDENTS ASK MORE AND BETTER QUESTIONS
}

By Melissa Zrada, Kim A. Kastens, and Margie Turrin

Over the last several years, our research group has embarked on an investigation of what kinds of questions undergraduates ask as they work with Earth science data visualizations (Kastens et al., 2019). This work led to the creation of a taxonomy of student questions, with overarching categories such as Questions about the Data and Questions about the Earth. Once we had acquired a multitude of student responses, we sought answers to our own research questions: What kinds of questions are students asking? What qualifies as a "good question"? How can we encourage students to ask more and better questions?

\section{WHY IS STUDENT QUESTION- ASKING IMPORTANT?}

Asking questions and seeking answers is how science progresses. Questions have the power to drive inquiry and challenge us to think in different ways. The US National Academy of Sciences identifies question-asking first in their series of eight "Practices of Science \& Engineering," and describes questions as "the engine that drives science and engineering" (National Research Council, 2012, p. 54). Asking many questions also provides students with practice in prioritizing which questions to answer-an essential skill for researchers.

For instructors, questions can act as an indicator of student knowledge and interest, and thus guide instruction. Questions can reveal critical knowledge gaps and misconceptions, or areas of deep thought and consideration. Attending to interests revealed by student-generated questions may forestall the situation described by the student who told Jonathan Osborne, the president of the National Association for Research in Science Teaching, "the trouble with school science is that it provides uninteresting answers to questions we have never asked" (Osborne, 2006, p. 2).

For graduates, the ability and habit of mind of asking incisive questions pays benefits outside the classroom. Individuals who have been taught to ask questions about their world become natural lifelong learners, regardless of career path. With countless sources of information at our fingertips today, this is a skill of increasing importance.

\section{HOW TO ENCOURAGE STUDENT QUESTION-ASKING}

The first step is to elevate the asking of abundant, curiosity-driven, studentgenerated questions as a valuable and legitimate teaching goal in your own mind. Next, send the message to students that asking questions is an expected part of doing science. In a traditional classroom environment, the "question-askers" are the teachers. Students seldom get the opportunity to ask their own questions. When they do, it may be limited to a simple, "does anyone have any questions?" to which only the boldest few typically respond.

A recent tweet by a Louisiana math teacher gained popularity when she challenged educators to rephrase how they prompt student questions:

Two years ago, I was saying "do you have any questions?" Last year I switched to "what questions do you have?" It made a difference. Today I tried "ask me two questions." And they did! And those?s led to more?s. It amazes me that the littlest things have such a big impact!

(https://twitter.com/MrsSasser/status/ 1034118861354950656)

This simple rephrasing from "do you have any questions?" to "what questions do you have?" conveys that you as the instructor anticipate and welcome questions, and that an expected part of learning new material is to generate questions around it.

While some students will feel comfortable announcing their questions in front of the class, others may be more hesitant. Some may come from cultural or family backgrounds where children were discouraged from asking questionsespecially of authority figures. Educators can employ various strategies to give students frequent practice at asking questions in a low-stakes format. Students can engage in a "turn and talk," in which they discuss something they are wondering about with a nearby classmate. Alternatively, students could be tasked with completing an exit slip in which they are asked to write one question they had about the lecture or lab that day.

Finally, question-generation can be assigned as part of a formal written assignment, to be completed individually or in small groups. Such an exercise transforms question-asking from an optional to an expected tool for learning, and positions question-asking as a valued science skill for which students will be held accountable. Although many such written assignments are imaginable, one approach that is particularly effective in teaching about the ocean is having students ask questions while viewing data. 


\section{ASKING QUESTIONS ABOUT EARTH FROM DATA}

Throughout their childhoods, the majority of questions that students heard or asked were addressed to another person, with the expectation or hope that the other person would provide the answers. Asking research questions in science requires re-engineering one's capacity for question-asking into a tool that directs questions away from other human beings, and toward real-world phenomena that are not capable of answering in words. Oceanographers and other scientists ask questions of data and seek answers in data.

Our research shows that students can do the same. We recruited undergraduates from a wide range of majors, from multiple institutions, spanning from first-years to seniors. We gave students either an iPad app (Polar Explorer: Sea Level; Ryan et al., 2015) that gave interactive access to a suite of data maps pertaining to sea level rise, or a paper atlas with the same data maps as the app. We asked them to either write down as many questions as they could about what they were viewing or to write down questions they would like to ask the scientists who collected the data.
We found that students generated a rich and nuanced collection of questions, inspired by the intriguing patterns revealed in the provided oceanographic and atmospheric data (Figure 1). Interestingly, there was no discernible difference in question quality between those using the app and those studying the atlas-students asked good questions regardless of the presentation medium. The most abundant type of question we received was questions about causality. Students noticed something distinctive in the data, such as a spatial pattern or temporal trend, and asked: Why is the Earth this way? How did it get to be this way? These questions contrasted with a smaller number of questions about consequences. Students noticed something distinctive in the data and asked about consequences for human society, for life forms, or for other parts of the Earth system. Along with questions about consequences, we also received questions about how a situation discernible in the data could be mitigated or approached with adaptation.

In addition to questions about how Earth works, students asked questions about the data themselves. The source of data behind a visualization can be mysterious to a student, especially when the data are regional or global in scale, as they were in our study. Eighty-three percent of our participants asked at least one question about how data had been collected or processed, or how a mapped parameter had been measured. This indicates curiosity about how the data were obtained, and how they were transformed into the "pictures" the students were seeing.

Based on our research findings, we would encourage instructors to have students generate questions about data before any conclusions or explanations about the data are provided, and to write down their questions as a formal assignment. In this approach, students are able to reflect on their own understanding and potentially form their own hypotheses. They can then work in groups to share and discuss their questions and ideas. As answers, or possible answers, emerge through investigation and instruction, students are more invested in what they are learning. They view the emerging insights as desired answers to questions they themselves have wondered about, rather than factoids being dropped on them.
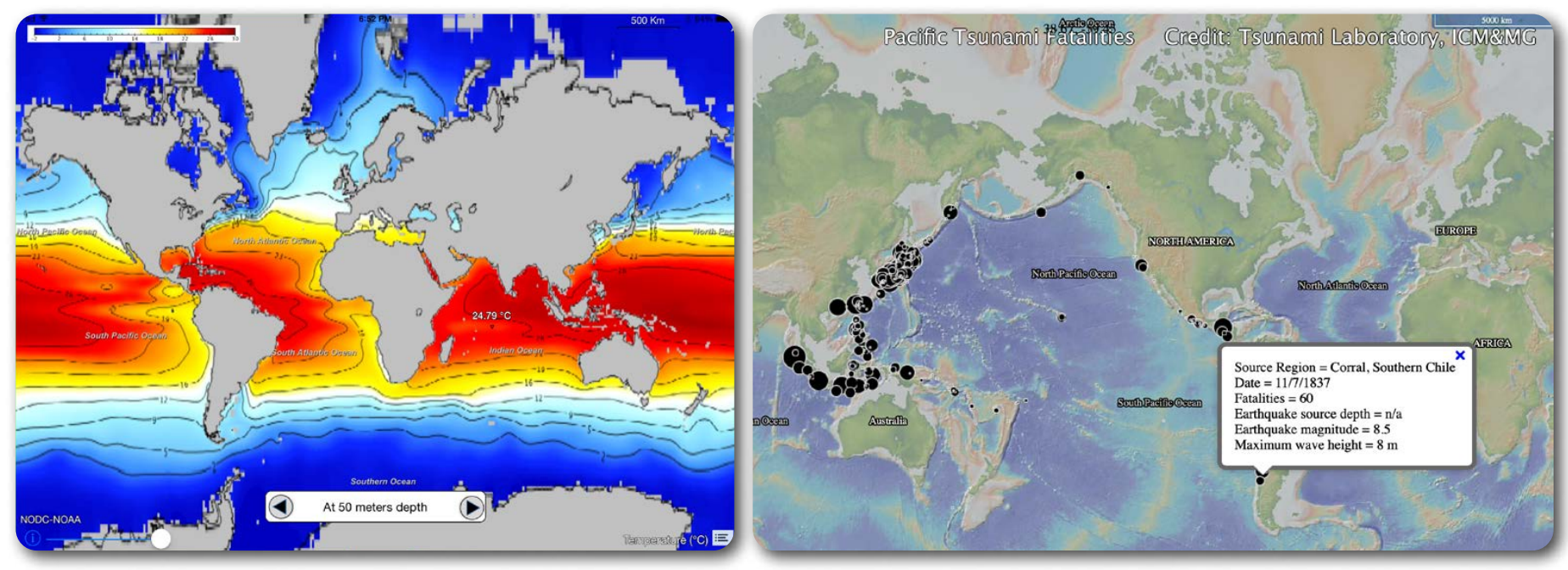

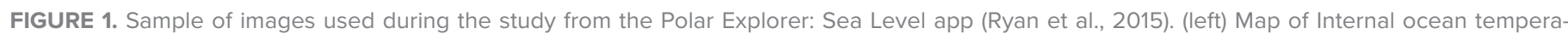

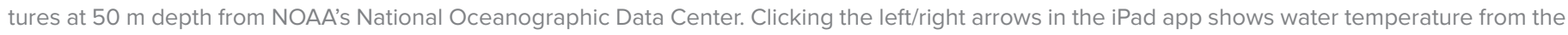

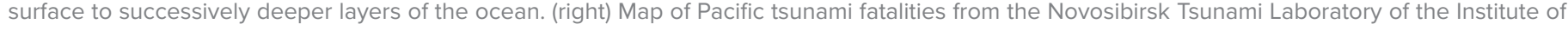

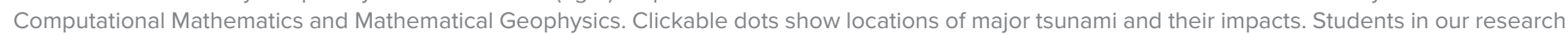
study were able to generate a wide range of questions about Earth and the data from visualizations such as these. 


\begin{tabular}{|c|c|c|}
\hline $\begin{array}{l}\text { BLOOM'S } \\
\text { LEVEL }\end{array}$ & QUESTION TYPE & EXAMPLE \\
\hline \multirow{2}{*}{ Create } & $\begin{array}{l}\text { Departure from Model } \\
\text { What I am seeing in the data does not match what I expected } \\
\text { from my prior understanding; why is that? }\end{array}$ & If it's all so cold, shouldn't more of it be frozen? \\
\hline & $\begin{array}{l}\text { Process/Mechanism/Hypothesis } \\
\text { Could it be that what I am seeing in the data is caused or } \\
\text { influenced by process } X \text { or mechanism } Y \text { ? }\end{array}$ & $\begin{array}{l}\text { Does ocean pollution influence the change (increase) in } \\
\text { temperature (water)? }\end{array}$ \\
\hline $\begin{array}{l}\text { Evaluate/ } \\
\text { Analyze }\end{array}$ & $\begin{array}{l}\text { Distinct Feature, Pattern, or Trend } \\
\text { What causes or caused a distinct feature, pattern, or trend that } \\
\text { I am seeing in the data? }\end{array}$ & Why is the North Atlantic so much warmer than everywhere else? \\
\hline Analyze & $\begin{array}{l}\text { Relationship Between Phenomena } \\
\text { Is there a relationship, or what kind of relationship is there, } \\
\text { between what I am seeing and something else? }\end{array}$ & $\begin{array}{l}\text { Does the temperature of the land correlate with the temperature } \\
\text { of the water surrounding it? }\end{array}$ \\
\hline \multirow{3}{*}{ Apply } & $\begin{array}{l}\text { Mitigation/Adaptation/Intervention } \\
\text { How can the situation I am seeing in the data be mitigated or } \\
\text { adapted to? }\end{array}$ & $\begin{array}{l}\text { Is China doing anything currently to decrease human impact on } \\
\text { climate change? }\end{array}$ \\
\hline & $\begin{array}{l}\text { Earth Consequences } \\
\text { What are the consequences of what I am seeing for living, } \\
\text { human, or physical systems? }\end{array}$ & $\begin{array}{l}\text { Are big cities in the area where temperature is } 26^{\circ} \mathrm{C} \text { or above } \\
\text { vulnerable to rising sea levels? }\end{array}$ \\
\hline & How Was Data Collected/Determined/Processed/Measured? & $\begin{array}{l}\text { At different depths, are some readings gathered more or less } \\
\text { frequently? }\end{array}$ \\
\hline Understand & Please Explain (the data) & What does it mean when the ocean gets more and more red? \\
\hline
\end{tabular}

\section{HOW TO RECOGNIZE AND ENCOURAGE BETTER QUESTIONS}

Once your students begin to ask more questions, you may start to wonder: What is a "good question"? In our research, we developed a hierarchy of question types (Table 1) based on a well-established model of cognitive levels-Bloom's Taxonomy (Bloom et al., 1956). The simplest questions, from a cognitive perspective, are ones in which the student is asking for an explanation of what the data are about or how to read the symbols. At the middle levels are questions in which students have noticed something they find intriguing about the data and are asking: Why? So what? What can we do about this? At the most cognitively demanding level, students are integrating their existing knowledge of Earth processes with information extracted from the data to test models or hypothesize about processes.

An educator could look at a Please Explain question and think that it is not as "good" or as deep as a Departure from Model question. Yet, we would argue that all questions are useful questions if they advance students' understanding of a topic. As educators, we should strive to honor all questions, because students come into our classes with various levels of expertise. Even the most expert scientists have to start with Please Explain questions when confronted with newly encountered data types. As students continue to grow as scientists, you can steer them toward asking higher level questions. Feel free to share Table 1 with your students, and challenge them to ask questions at all levels of Bloom's Taxonomy.

\section{CONCLUSION}

Question-asking is a valuable skill that students will continue to use throughout their lives. Questions allow students to dive deeper into concepts and become more invested in their own learning. Our research demonstrates that oceanographic and atmospheric data visualizations can be excellent catalysts for eliciting student questions, even from students with little prior knowledge of these topics. @

\section{REFERENCES}

Bloom, B.S., M.D. Engelhart, E.J. Furst, W.H. Hill, and D.R. Krathwohl. 1956. Taxonomy of Educational Objectives: The Classification of Educational Objectives: Handbook I: The Cognitive Domain. Longmans, Green and Co Ltd., London.

Kastens, K.A., M. Zrada, and M. Turrin. 2019. What kinds of questions do students ask while exploring data visualizations? Journal of Geoscience Education, https://doi.org/10.1080/10899995.2019. 1675447.

National Research Council. 2012. A Framework for K-12 Science Education: Practices, Crosscutting Concepts, and Core Ideas. The National Academies Press, Washington, DC, https://www. nap.edu/read/13165/chapter/7.

Osborne, J. 2006. Message from the President. E-NARST News 49(2):1-2, https://www.narst.org/ news/e-narstnews_july_2006_.pdf.

Ryan, W.B.F., J. Coplan, A. Goodwillie, D. Porter, J. Taylor, and M. Turrin. 2015. Polar Explorer: Sea Level App, http://www.polar-explorer.org.

\section{AUTHORS}

Melissa Zrada (melissa.zrada@tcnj.edu) is Assistant Professor, Integrative STEM Education, School of Engineering, The College of New Jersey, Ewing, NJ, USA. Kim A. Kastens is Special Research Scientist, and Margie Turrin is Director of Educational Field Programs, both at Lamont-Doherty Earth Observatory of Columbia University, Palisades, NY, USA.

\section{ARTICLE CITATION}

Zrada, M., K.A. Kastens, and M. Turrin. 2019. How to help your students ask more and better questions. Oceanography 32(4):204-206, https://doi.org/ 10.5670/oceanog.2019.404. 